\title{
The Nitric Oxide-cGMP Signaling Pathway Differentially Regulates Presynaptic Structural Plasticity in Cone and Rod Cells
}

\author{
Nan Zhang, ${ }^{1}$ Annie Beuve, ${ }^{2}$ and Ellen Townes-Anderson ${ }^{1}$ \\ Departments of ${ }^{1}$ Neurology and Neurosciences and ${ }^{2}$ Pharmacology and Physiology, University of Medicine and Dentistry of New Jersey-New Jersey \\ Medical School, Newark, New Jersey 07103-2714
}

\begin{abstract}
Although abundant structural plasticity in the form of axonal retraction, neurite extension, and formation of presynaptic varicosities is displayed by photoreceptors after retinal detachment and during genetic and age-related retinal degeneration, the mechanisms involved are mostly unknown. We demonstrated recently that $\mathrm{Ca}^{2+}$ influx through cGMP-gated channels in cones and voltage-gated L-type channels in rods is required for neurite extension in vitro (Zhang and Townes-Anderson, 2002). Here, we report that the nitric oxide (NO)-cGMP signaling pathway is active in photoreceptors and that its manipulation differentially regulates the structural plasticity of cone and rod cells. The NO receptor soluble guanylyl cyclase (sGC) was detected immunocytochemically in both cone and rod cells. Stimulation of sGC increased cGMP production in retinal cultures. In cone cells, quantitative analysis showed that NO or cGMP stimulated neuritic sprouting; this stimulatory effect was dependent on both $\mathrm{Ca}^{2+}$ influx through cGMP-gated channels and phosphorylation by protein kinase G (PKG). At the highest levels of cGMP, however, cone outgrowth was no longer increased. In rod photoreceptors, NO or cGMP consistently inhibited neuritic growth in a dose-dependent manner; this inhibitory effect required PKG. When NO- cGMP signaling was inhibited, changes in the neuritic development of cone and rod cells were also observed but in the opposite direction. These results expand the role of cGMP in axonal activity to adult neuritogenesis and suggest an explanation for the neurite sprouting observed in an autosomal recessive form of retinitis pigmentosa that is characterized by high cGMP levels in photoreceptor layers.
\end{abstract}

Key words: neurite and varicosity formation; neuritic sprouting; cone; rod; nitric oxide; cGMP; soluble guanylyl cyclase

\section{Introduction}

cGMP, which is produced by soluble guanylyl cyclase (sGC) in response to nitric oxide (NO), is an important signaling molecule in axonal development. cGMP modulates growth cone activity in a variety of neuronal cell types from both mammalian and amphibian species (Song et al., 1998; Polleux et al., 2000; Schmidt et al., 2002; Xiang et al., 2002; Nishiyama et al., 2003). For example, changes in cGMP content determine whether guidance factors such as semaphorin III attract or repulse neuritic growth in developing spinal cord neurons (Song et al., 1998). In some adult invertebrate neurons, NO donors stimulate lengthening of growth cone filopodia and slow neurite growth (Van Wagenen and Rehder, 1999, 2001; Trimm and Rehder, 2004). Additionally, we reported that an analog of cGMP stimulates the formation of presynaptic varicosities in cone photoreceptors but inhibits varicosity formation in rod photoreceptors isolated from adult

Received Aug. 4, 2004; revised Jan. 28, 2005; accepted Jan. 29, 2005.

This work was supported by National Institutes of Health Grants EY12031 (E.T.-A.) and GM067640 (A.B.) and by the F. M. Kirby Foundation. We thank Roma Chawla and Youhua Zhu for invaluable participation in the quantitative analyses. We thank Fu-Jung Chang, Dr. Qian Sun, and Roshni Ali for excellent technical support on the RIAs.

Correspondence should be addressed to Dr. Ellen Townes-Anderson, Department of Neurology and Neurosciences, University of Medicine and Dentistry of New Jersey-New Jersey Medical School, 185 South Orange Avenue, Newark, NJ 07103. E-mail: andersel@umdnj.edu.

DOI:10.1523/JNEUROSCI.3195-04.2005

Copyright $\odot 2005$ Society for Neuroscience $\quad$ 0270-6474/05/252761-10\$15.00/0 salamander retina (Zhang and Townes-Anderson, 2002). Thus, cGMP, which affects neuronal differentiation, may also play a role in the structural synaptic plasticity of mature neurons.

In adult photoreceptors, cGMP is a key signaling molecule for the transduction of light into a membrane potential change in the outer segments where the membrane-associated or particulate form of guanylyl cyclase (pGC) and cGMP-gated channels are present (Pugh et al., 1997). However, pGC is also present in photoreceptor synaptic terminals (Liu et al., 1994; Cooper et al., 1995), and cGMP-gated channels occur in cone synaptic terminals (Rieke and Schwartz, 1994; Savchenko et al., 1997). In addition, many components of the NO-cGMP signaling pathway (supplemental Fig. 1, available at www.jneurosci.org as supplemental material) are present in photoreceptors: nitric oxide synthase (NOS) is present in cone and rod inner segments, the surrounding horizontal neurons, and Müller glia cells (Liepe et al., 1994; Haberecht et al., 1998); protein kinase G (PKG) type I and possibly type II are present in photoreceptor inner segments and the outer synaptic layer where photoreceptor terminals lie (Gamm et al., 2000); and cGMP-phosphodiesterase (PDE) is present in outer segments but also rod inner segments (Ueno et al., 1984). At present, sGC protein has been observed only in cone cells (Haberecht et al., 1998). However, mRNA for sGC is present in rat outer retina, which consists predominantly of rod cells (Ahmad and Barnstable, 1993). Finally, abnormally high cGMP 
production, resulting from the mutation of the rod gene for the $\beta$ subunit of cGMP-PDE type 6, is known to be implicated in a form of retinitis pigmentosa (RP). In its murine model, the retinal degeneration 1 (rd1) mouse (Farber and Lolley, 1974), cone cells have been reported to grow long neurites with presynaptic varicosities (Fei, 2002), whereas the synaptic development of the rod cells is stunted (Blanks et al., 1974).

To investigate whether NO-cGMP signaling is involved in adult axonal sprouting in general and in the synaptic remodeling by photoreceptors seen in one form of retinal degenerative disease in particular, cultures of isolated retinal neurons were maintained with agonists and antagonists of the pathway and assessed for growth. NO and cGMP levels were determined with the Griess reaction and radioimmunoassay (RIA), respectively; the presence of sGC was examined by immunocytochemistry.

\section{Materials and Methods}

Antibodies and chemicals. The monoclonal antibody 4D2 against the opsin of M (red) rod photoreceptors (Hicks and Molday, 1986) was a gift from Dr. R. Molday (University of British Columbia, Vancouver, British Columbia, Canada); its specificity has been demonstrated previously in the salamander retina (Mandell et al., 1993). Polyclonal antibodies raised against the $\alpha$ (5551) and $\beta$ (5552) subunits of human soluble guanylyl cyclase were gifts from Dr. A. Sitaramayya (Oakland University, Rochester, MI). The salamander-specific antibody Sal-1 in mouse hybridoma supernatant was generously provided by Dr. P. MacLeish (Morehouse School of Medicine, Atlanta, GA). Goat anti-mouse rhodamine and goat antimouse Alexa Fluor (AF) antibodies were purchased from Molecular Probes (Eugene, OR). The Vectastain Elite avidin-biotinylated horseradish peroxidase (HRP) complex (ABC) staining kit was purchased from Vector Laboratories (Burlingame, CA). Superoxide dismutase (SOD) and catalase were purchased from Roche Diagnostic. L-cis-diltiazem (Lcd), cGMP, 8-bromocGMP (8Br-cGMP), IBMX, 1H(1,2,4)oxadiazolo-[4,3-a]quinozalin-1-one (ODQ), and $N^{\omega}$-nitro-L-arginine methyl ester (L-NAME) were purchased from Sigma (St. Louis, MO). (+)-S-nitroso- $N$-acetylpenicillamine (SNAP), 3-(5-hydroxymethyl-2-furyl)-1-benzylindazole(YC-1), andguanosine 3', 5' cyclic monophosphorothioate, 8-(4-chlorophenylthio)-, Rp-isomer (Rp-8pCPT-cGMPS) were purchased from Calbiochem (La Jolla, CA). YC-1 was dissolved in 100\% DMSO; all other reagents were dissolved in distilled $\mathrm{H}_{2} \mathrm{O}$.

Isolation and culture of photoreceptors. Adult, aquatic-phase salamanders (Ambystoma tigrinum; 16-30 cm in length) were obtained from Charles Sullivan (Nashville, TN). Animals were adapted to a $12 \mathrm{~h}$ light/dark cycle in a cold room $\left(\sim 5^{\circ} \mathrm{C}\right)$ for at least $3 \mathrm{~d}$ before experiments. To reduce the influence of circadian activity, retinas were always obtained 3-4 h after lights on. Animals were decapitated and pithed according to protocols approved by the Institutional Animal Care and Use Committee at the University of Medicine and Dentistry of New JerseyNew Jersey Medical School (Newark, NJ). Dissociation of the retina was performed as described previously using enzymatic digestion with papain and trituration (Mandell et al., 1993; Zhang and Townes-Anderson, 2002). Cells were plated onto glass coverslips coated with goat antimouse IgG antibody and Sal-1 antibody (MacLeish et al., 1983). Cells were grown in a serum-free medium containing $108 \mathrm{~mm} \mathrm{NaCl}, 2.5 \mathrm{~mm}$ $\mathrm{KCl}, 2 \mathrm{~mm}$ HEPES, 1 mм $\mathrm{NaHCO}_{3}, 0.5 \mathrm{~mm} \mathrm{NaH} \mathrm{NO}_{4}, 1 \mathrm{~mm}$ sodium pyruvate, $0.5 \mathrm{~mm} \mathrm{MgCl}_{2}, 16 \mathrm{~mm}$ glucose, $1.8 \mathrm{~mm} \mathrm{CaCl}_{2}, 7 \%$ medium 199 (Invitrogen, San Diego, CA), 1\% minimum essential medium (MEM) vitamin mix, $0.1 \times$ MEM essential amino acids, $0.1 \times$ MEM nonessential amino acids, $2 \mathrm{~mm}$ glutamine, $2 \mu \mathrm{g} / \mathrm{ml}$ bovine insulin, $1 \mu \mathrm{g} / \mathrm{ml}$ transferrin, $5 \mathrm{~mm}$ taurine, $0.8 \mu \mathrm{g} / \mathrm{ml}$ thyroxine, $10 \mu \mathrm{g} / \mathrm{ml}$ gentamicin, and 1.0 $\mathrm{mg} / \mathrm{ml}$ bovine serum albumin. Cells were maintained in a dark, humidified chamber at $10^{\circ} \mathrm{C}$.

Identification of cultured photoreceptors. Among mixed populations of cultured retinal neurons, photoreceptors can be identified by the presence of an ellipsoid, which is an accumulation of mitochondria in the inner segment (see Fig. 1C, arrowhead). Cone and rod photoreceptors were further identified by the absence or presence of $M$ (red) rod opsin immunostaining with 4D2. Immunostaining followed previously de- scribed procedures (Zhang and Townes-Anderson, 2002). Although S (green) rod cells were excluded from the rod cell category by this method, they are only $1.3 \%$ of the total photoreceptor population in tiger salamander (Sherry et al., 1998). Combined application of 4D2 immunostaining and morphology identified cone and rod cells positively.

Western blot. Neural retinas were homogenized at $4^{\circ} \mathrm{C}$ with a lysis buffer containing $50 \mathrm{~mm}$ Tris Base, $150 \mathrm{~mm} \mathrm{NaCl}, 10 \mathrm{~mm} \mathrm{MgCl}_{2}, 1 \%$ Triton X-100, $0.1 \%$ SDS, $0.5 \%$ sodium deoxycholate, $10 \mu \mathrm{g} / \mathrm{ml}$ leupeptin, $10 \mu \mathrm{g} / \mathrm{ml}$ aprotinin, and $1 \mathrm{~mm}$ phenylmethyl sulfonyl fluoride (PMSF). Cell lysates were centrifuged at $14,000 \times g$ at $4^{\circ} \mathrm{C}$ for $10 \mathrm{~min}$. Protein concentration was estimated by the method of Bradford (1976) using the Bio-Rad (Hercules, CA) protein assay kit II. The sample was boiled for $3 \mathrm{~min}$ in $2 \times$ Laemmli sample buffer. Equivalent $(50 \mu \mathrm{g})$ amounts of proteins per sample were subjected to electrophoresis on a $10 \%$ SDS acrylamide gel. The gel was then blotted onto a nitrocellulose membrane that was blocked for $1 \mathrm{~h}$ in a $4 \%$ suspension of dried milk in washing buffer and incubated overnight at $4^{\circ} \mathrm{C}$ with either sGC- $\alpha$ or sGC- $\beta$ antibody (1:500). Membranes were washed and incubated for $1 \mathrm{~h}$ at room temperature with alkaline phosphatase-conjugated anti-mouse $\operatorname{IgG~(1:5000)~and~stained~with~Sigma~Fast~5-bromo-4-chloro-3-indolyl-~}$ phosphate/nitro blue tetrazolium tablets.

Immunocytochemistry. The $\mathrm{ABC}$ technique, used to label sGC, was based on a previously reported procedure (Nachman-Clewner et al., 1999 ) with modification. (1) Photoreceptors were fixed with $4 \%$ paraformaldehyde in $0.125 \mathrm{M}$ phosphate buffer. (2) Cells rinsed with PBS were incubated in target unmasking fluid (Signet Laboratories, Dedham, $\mathrm{MA}$ ) for $10 \mathrm{~min}$ at $90^{\circ} \mathrm{C}$ followed by PBS washes and then incubated in $0.5 \% \mathrm{H}_{2} \mathrm{O}_{2}$ diluted in PBS for $6 \mathrm{~min}$ at room temperature, followed by PBS washes. (3) After incubation for $1 \mathrm{~h}$ at room temperature in a goat serum dilution buffer (GSDB) with $0.1 \%$ Triton X-100, cells were incubated at $4{ }^{\circ} \mathrm{C}$ overnight with primary antibodies diluted 1:50 in GSDB with $0.1 \%$ Triton X-100. To identify rod cells, 4D2 antibody (1:25) was also added. For negative controls, no primary antibodies were added. (4) Rinsed cells were incubated with secondary antibodies, goat anti-mouse antibody conjugated to $\mathrm{AF}$ (1:35) to label rod opsin, and goat anti-rabbit antibody conjugated with biotin (1:200) in Triton-free GSDB for $1 \mathrm{~h}$ at room temperature. (5) Cells washed with PBS were incubated with avidin conjugated to HRP for $45 \mathrm{~min}$ at room temperature. (6) Staining was developed with stable diaminobenzidine (Invitrogen), and cells were stored in PBS.

Quantification of cell outgrowth. Cone cells were viewed with phasecontrast microscopy, whereas $4 \mathrm{D} 2$-stained rod cells were viewed with fluorescence microscopy. Digital images of cells were captured by a CCD camera and analyzed with ImagePro software (version 4.1; Media Cybernetics, Silver Spring, MD). Any growth extending $>5 \mu \mathrm{m}$ from the soma was considered to be a process. A process was defined as a $1^{\circ}$ process before it branched, a $2^{\circ}$ process after branching, or a $3^{\circ}$ process after additional branching. Primary processes were further divided into thick, thin, and lamellipodial-like processes. A varicosity was defined as a swelling along a neuritic process with a diameter larger than $0.5 \mu \mathrm{m}$.

Radioimmunoassay. At the end of the culture period, cell density was determined for each culture, medium was then gently removed, and 215 $\mu \mathrm{l}$ of medium containing $2.3 \%$ perchloric acid was added to each culture to lyse the cells. The lysed cell extract was collected and stored at $-20^{\circ} \mathrm{C}$. For RIA, samples were thawed, and $15 \mu \mathrm{l}$ of $10 \mathrm{~N} \mathrm{KOH}$ was added to each sample for neutralization. Measurements of cGMP by RIA were conducted as reported by Domino et al. (1991) with modification. Briefly, cGMP in samples and cGMP standards were acetylated with a triethylamine and acetic anhydride mixture. Samples were diluted (usually 1:2) for the assay. The concentration of cGMP was determined from a standard curve $(5,10,20,40,50,100$, and $200 \mathrm{fmol}$ of cGMP). To each sample and standards, 20,000 cpm of ${ }^{125}$ I-labeled cGMP and $20 \mu$ l of anti-cGMP antibody (1:3333) were added. After overnight incubation at $4^{\circ} \mathrm{C}$ with PEG-8000 (polyethylene glycol), the complex formed by cGMP antibody and ${ }^{125}$ I-labeled cGMP was precipitated by centrifugation, and radioactivity was determined by a Cobra II Auto-Gamma counter (PerkinElmer, Wellesley, MA). The most accurate range of the standard curve was 10100 fmol cGMP, consistent with that reported by Domino et al. (1991).

Measurement of nitrite. Nitrite is the only stable product of NO after 
spontaneous autoxidation. Nitrite concentration was examined with the Griess reaction (Aggarwal and Mehta, 1996). Briefly, $100 \mu$ l of culture supernatant was mixed with $100 \mu \mathrm{l}$ of Griess reagent (1\% sulfanilamide, $0.1 \% N$-1-naphthyl-ethylenediamine dihydrochloride, $2.5 \%$ phosphoric acid), and absorbance at $490 \mathrm{~nm}$ was measured in a microplate autoreader (Biotek Instruments, Wincoski, VT). Nitrite concentration (micromolar) was determined according to a standard curve created by sodium nitrite.

Data analysis. The data derived from quantitative analysis of cell growth, cGMP RIA, and the Griess reaction were all expressed as mean \pm SEM. Statistical comparisons between two groups were made with Student's $t$ test if the normality and equal variance tests were passed or with Mann-Whitney rank-sum test if the normality and equal variance tests failed. Comparisons among multiple groups were made with one-way ANOVA with Dunnett's method of post hoc analysis. Statistical analysis was performed using SigmaStat software (version 3.0; SPSS, Chicago, IL). Graphs were created using SigmaPlot (version 8.0; SPSS).

\section{Results}

We established previously that cultures of adult salamander retinal neurons can be maintained for weeks in a defined (serumfree) medium (Mandell et al., 1993). Although the cultures contain all neural cell types, $\sim 50 \%$ of the cells are cone and rod photoreceptors. The photoreceptors grow new neurites, form presynaptic varicosities, and eventually develop functional synapses with neighboring cells (MacLeish and Townes-Anderson, 1988). Much of the growth occurs within the first $3 \mathrm{~d}$ of culture. Filopodial processes sprout after $\sim 24$ h; by $3 \mathrm{~d}$, lamellipodia and thickened neurites have formed. The latter contain microtubules and presynaptic varicosities, filled with synaptic vesicles (Mandell et al., 1993), along their length and at their tips (Figs. 1, 2, 4, control cone and rod cells).

The role of NO-cGMP signaling was examined by pharmacologically altering the signaling pathway (supplemental Fig. 1, available at www.jneurosci.org as supplemental material). In most experiments, reagents were applied to retinal cultures for $3 \mathrm{~d}$ beginning immediately after cell plating. All the photoreceptors studied were without outer segments. This removed a possible source of confounding activity from the cGMP-related transduction machinery, such as outer segment pGC and cGMP-gated channels. Rod cells grow processes both after their synaptic terminals have been damaged or torn off during the isolation procedure (axotomy) and when the terminal remains but the postsynaptic processes have been removed (denervation) (Nachman-Clewner and Townes-Anderson, 1996). Cone cells always retain their synaptic terminals, which lie immediately basal to the nucleus, after isolation. Technically, rod cells that have been axotomized are regenerating their axonal components. But, for simplicity, we refer to all process formation as neuritic growth or sprouting. The photoreceptor cell types, even without their outer segments, remain distinctive in their morphology throughout the culture period (Sherry et al., 1996); their identity in most cases was also verified by immunocytochemistry.

\section{Effects of NO on neuritic growth and varicosity formation by photoreceptors}

To determine the endogenous activities of the NO-cGMP signaling pathway in retinal cultures, the concentration of the stable $\mathrm{NO}$ end product nitrite in the culture supernatant and the content of cGMP in the retinal cell lysate were measured by the Griess reaction and RIA, respectively, after 1,3 , and $5 \mathrm{~d}$ in vitro. The nitrite concentrations in the 1-, 3-, and 5-d-old culture supernatants were $0.4,1.3$, and $1.7 \mu \mathrm{M}$, respectively. They increased with time, indicating a continuous basal level production of NO (Fig.
1A). The cGMP content in the 1-, 3-, and 5-d-old retinal cell lysates were 93.0, 139.5, and 156.1 fmol per 200 cells, respectively. Because cGMP is hydrolyzed by PDE, the constant level over time indicates steady cGMP production by retinal cells (Fig. $1 B$ ). Thus, the NO-cGMP signaling pathway is continuously active in cultures of retinal cells containing photoreceptors.

To increase NO-cGMP signaling, SNAP (100 $\mu \mathrm{M})$, an NO donor widely used to elevate NO levels in cells (Wang et al., 1999), was applied to cultured photoreceptors. NO activates sGC, increasing basal enzyme activity several hundred-fold (Garthwaite, 1995). Because NO can also react with the endogenous free radical superoxide anion produced by cellular metabolism and form peroxynitrite, which is cytotoxic when accumulated (Lipton et al., 1993; Cheung et al., 2000), SOD (50 U/ml) and catalase $(50 \mathrm{U} / \mathrm{ml})$ were also added to the medium. Cells were grown for 1 , 3 , and $5 \mathrm{~d}$, and nitrite and cGMP were measured at each time point. In supernatant from the 1-d-old cultures, $100 \mu \mathrm{M}$ SNAP elevated nitrite concentration from a basal level of $0.4-1.95 \mu \mathrm{M}$ $(p<0.001)$. In 3 - and 5-d-old culture supernatants, concentrations of nitrite remained higher than control samples (Fig. 1A). Levels of cGMP in all the cultures treated with SNAP were also significantly higher than control cultures (Fig. $1 B$ ). Because SNAP releases NO with an estimated half-life of 6-10 h (Q. Sun and A. Beuve, personal communication), return of cGMP to basal levels was anticipated by the $3 \mathrm{~d}$ time point in the absence of PDE inhibitors. Instead, $100 \mu \mathrm{M}$ SNAP significantly increased cGMP production by retinal cells for up to $5 \mathrm{~d}$ (Fig. $1 B$ ).

Next, the growth of neuritic structures was examined (Fig. $1 C-H)$. The number of processes, length of the longest process, and number of varicosities were assessed. Because the increases or decreases in length of the longest process followed the same pattern as the number of processes, these data have not been shown. Three-day-old control cone cells had, on average, 3.9 processes and 1.3 varicosities per cell (Fig. $1 C, G$ ). For 3-d-old control rod cells, there were, on average, 14.2 processes and 3.1 varicosities per cell (Fig. $1 D, H)$. The control cultures for SNAP experiments were treated with SOD and catalase; they had the same amount of growth as untreated cultures (data not shown; from analysis of 200 cells). In experimental cultures, three concentrations (10 $\mu \mathrm{M}$, $100 \mu \mathrm{M}$, and $1 \mathrm{~mm}$ ) of SNAP, plus SOD and catalase, were applied for $3 \mathrm{~d}$. In cone cells, $10 \mu \mathrm{M}$ SNAP caused a significant increase in the number of neuritic processes, by $25.4 \%$, and varicosities, by $34.9 \%$. One hundred micromolar SNAP caused an additional increase in both the number of neuritic processes, by $45.6 \%(p<$ $0.001)$, and varicosities, by $86.8 \%(p<0.001)$. The highest concentration (1 mM) of SNAP, however, did not cause additional growth (Fig. 1G). In rod cells, $10 \mu \mathrm{M}$ SNAP caused a slight but insignificant decrease in growth. With $100 \mu \mathrm{M}$ SNAP, however, there was a significant decrease in the number of neuritic processes, by $19.8 \%$, and varicosities, by $43.3 \%$. The highest concentration (1 mM) of SNAP caused an additional decrease in the number of neuritic processes, by $37.6 \%(p=0.001)$. The decrease in rod cell growth was not a result of cytotoxicity: there was no significant decrease in cell density in cultures treated with 1 mM SNAP (data not shown). However, without the removal of superoxide anion, SNAP induced inconsistent changes in the growth of neuritic structures by both cone and rod cells (data not shown). The broad, differential effects of NO on cone and rod cells were also evident when growth was analyzed in further detail. For cones, every type of process growth increased with 100 $\mu \mathrm{M}$ SNAP, most with statistical significance, whereas rod growth was consistently inhibited with major or primary processes and varicosities being most affected (Table 1). 

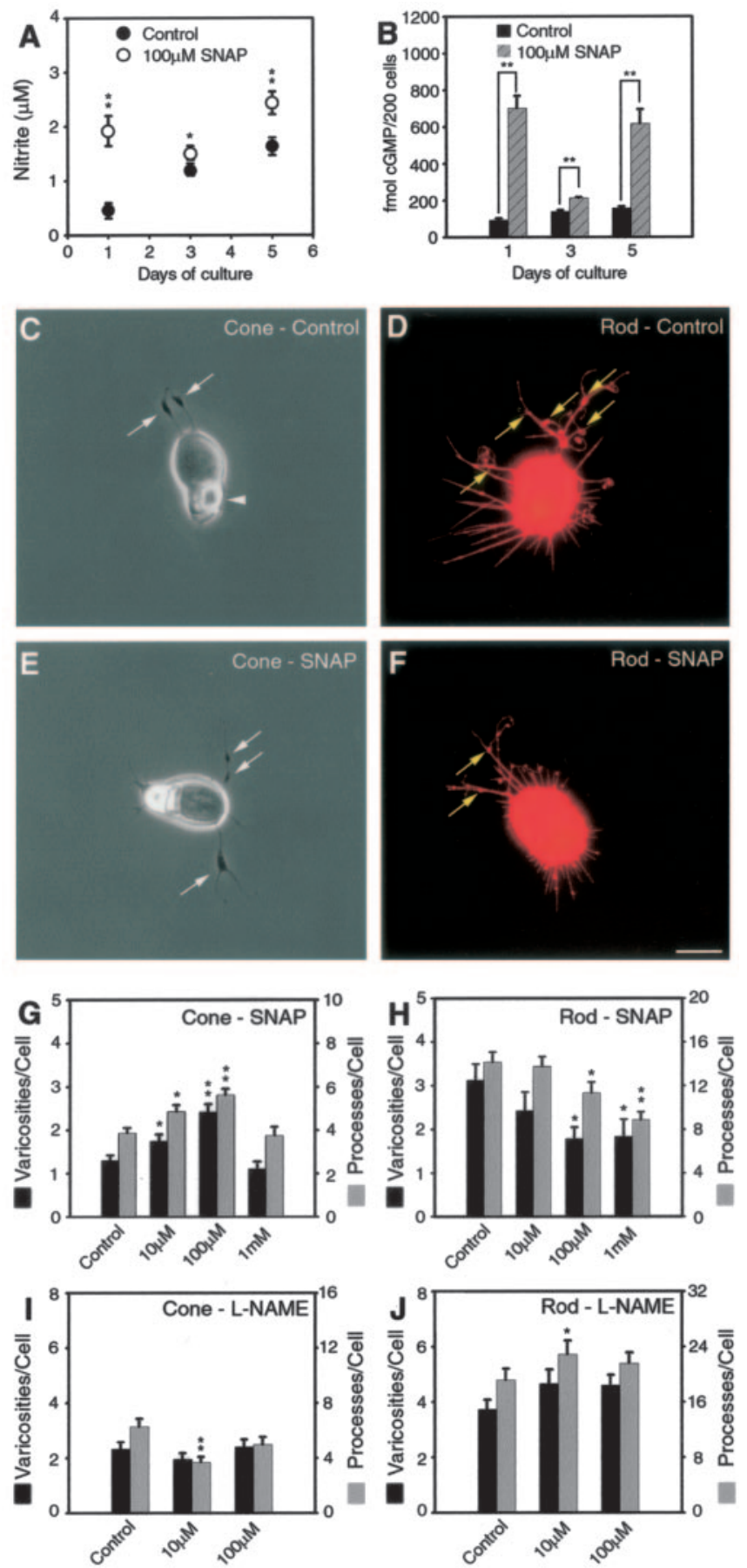

Figure 1. The NO donor SNAP or NOS inhibitor L-NAME increased and decreased growth, respectively, in cone cells. In rod cells, growth was affected in the opposite direction; it was decreased and increased by SNAP and L-NAME, respectively. $\boldsymbol{A}$, Nitrite levels were determined from culture supernatant. In control cultures, nitrite increased with time; nitrite production was consistently higher in the presence of SNAP. B, CGMP levels were obtained from cultured cells. Control cultures maintained a steady level of cGMP. With SNAP, CGMP levels were higher at all time points. $C$, An untreated cone cell shown with phase-contrast optics. Neuritic processes with vesicle-containing varicosities (arrows) are present at the basal or nuclear pole. A phase-bright ellipsoid, which consists of an accumulation of mitochondria, is at the apical pole of the cell (arrowhead). Because it is photoreceptor specific, it is used for cell identification. D, An untreated rod cell labeled for rod opsin shown by fluorescence microscopy. The cell has numerous processes. The thicker, neuritic processes emanating from the nuclear pole have multiple presynaptic varicosities (arrows) along their length. $\boldsymbol{E}$, A cone cell treated with SNAP (100 $\mu \mathrm{m})$ has more neuritic processes with branches and varicosities (arrows) than the control cell. $\boldsymbol{F}$, A rod cell treated with SNAP (100 $\mu \mathrm{m})$ has fewer processes and varicosities than the control cell. $\mathbf{C}-\boldsymbol{F}$,
$\mathrm{NO}$ in neuronal cells is produced from L-arginine by neuronal NOS (nNOS). L-NAME acts as a competitive inhibitor of L-arginine binding to NOS (Nathan, 1992). It blocks the activity of nNOS and endothelial NOS, although it does not effectively inhibit inducible NOS (iNOS) activity (Boer et al., 2000). We investigated the effects of inhibition of nNOS with L-NAME on the growth of neuritic structures by photoreceptors cultured for $3 \mathrm{~d}$. In cone cells, $10 \mu \mathrm{M} \mathrm{L}-\mathrm{NAME}$ caused a decrease in the number of processes by $41.1 \%$ ( $p<0.001)$, whereas $100 \mu \mathrm{M} \mathrm{L-NAME}$ caused a statistically marginal decrease in the number of processes, by $20.9 \%$ ( $p=0.097$ ) (Fig. $2 I$ ). In rod cells, $10 \mu \mathrm{M}$ L-NAME caused an increase in the number of processes by $19.4 \%$ $(p<0.05)$ and varicosities by $24.6 \%$ (not statistically significant). One hundred micromolar L-NAME also caused an increase in the number of processes and varicosities, although these increases were not statistically significant (Fig. $1 \mathrm{~J}$ ). However, 10 and $100 \mu \mathrm{M} \mathrm{L}-\mathrm{NAME}$ did cause an increase in the number of process branch points by $42.8 \%(p=0.054)$ and $42.2 \%(p=$ 0.038 ), respectively (data not shown). Increasing L-NAME concentration further appeared to be cytotoxic and was not systematically examined. Although the effects were not robust, inhibition of nNOS with L-NAME caused a slight inhibition of growth in cone cells and some stimulation of neurite formation in rod cells. The effects of L-NAME might have been reduced as a result of the induction of iNOS activity (Miller et al., 1996; Sennlaub et al., 2002).

In summary, the above results indicate that the endogenous NO-cGMP signaling pathway is continuously active in cultured salamander photoreceptors. The basal level of activity in the NOcGMP signaling pathway appears to permit neuritic growth and varicosity formation by both cone and rod photoreceptors. Increasing NO using SNAP increased cGMP, and long-term application of SNAP induced long-term production of cGMP from retinal cells, up to $5 \mathrm{~d}$. Increases in these signaling molecules produced differential morphological responses in cone and rod cells: stimulation of neuritic growth by cone cells but inhibition of that by rod cells. Decreases in NO-cGMP signaling by inhibition of NOS also appeared to induce differential morphological responses by cone and rod cells but, as might be expected, in the opposite direction: inhibition of cone growth and stimulation of rod growth.

\section{Soluble guanylyl cyclase in photoreceptors}

The observed increases in cGMP levels produced by SNAP are presumably attributable to the activation of sGC. Whether this enzyme exists in both rod and cone cells and specifically in salamander photoreceptors is unknown. The distribution of sGC in cultured salamander photoreceptors, therefore, was examined using antibodies raised against the $\alpha$ - and $\beta$-subunits of sGC in conjunction with $\mathrm{ABC}$ immunocytochemistry. The specificity of the antibodies was tested with Western blots of homogenized

$\leftarrow$

Cells from $3 \mathrm{~d}$ cultures. Scale bar, $10 \mu \mathrm{m} . \mathbf{G}-\boldsymbol{J}$, Quantitative analysis of process outgrowth and varicosity formation after $3 \mathrm{~d}$ of treatment. $\mathbf{G}$, Cone cells treated with 10 and $100 \mu \mathrm{m}$ SNAP had significant increases in the number of processes and varicosities. The highest concentration of SNAP, however, did not increase growth. $\boldsymbol{H}$, For rod cells, SNAP caused a dose-dependent decrease in the number of total processes and varicosities. I, For cone cells treated with L-NAME, only $10 \mu \mathrm{m}$ showed a significant decrease in the number of neuritic processes.J, Rod cells treated with 10 and 100 $\mu \mathrm{ML}$ LNAME had an increased number of processes and varicosities, although these increases reached statistically significance only for processes at $10 \mu \mathrm{m} . \boldsymbol{A}, \boldsymbol{B}, n=12$ cultures from two animals; $\mathbf{G}, \boldsymbol{H}, n=$ 800 cells in 16 culture dishes from two animals; $I, J, n=600$ cells in 12 culture dishes from two animals. ${ }^{*} p<0.05 ;{ }^{* *} p<0.001$. Error bars represent \pm SEM. 
A
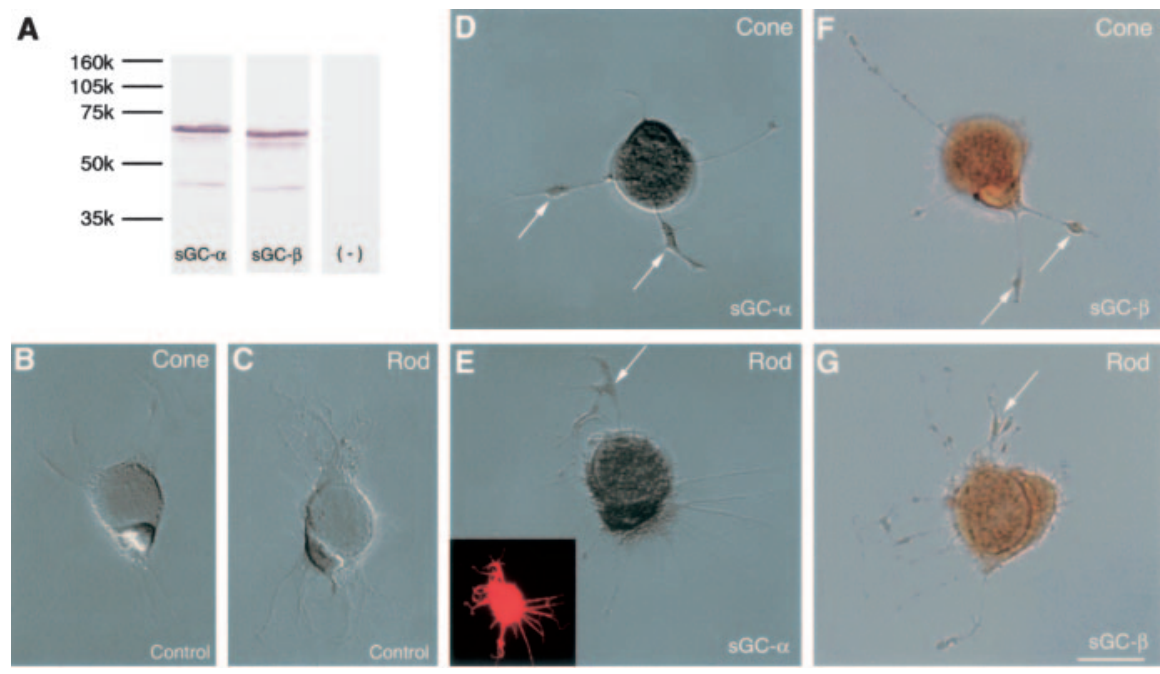

Figure 2. $s G C$ is expressed in both cone and rod cells cultured for $3 \mathrm{~d}$. $A$, Western blot of homogenized neural retina is shown. Major bands at $68 \mathrm{kDa}$ (left column) and $63 \mathrm{kDa}$ (middle column) were detected for the sGC $-\alpha$ and sGC- $\beta$ antibodies, respectively. There was no staining in the absence of primary antibodies (right column). $\boldsymbol{B}-\mathbf{G}, A B C$ immunocytochemistry is shown. $\boldsymbol{B}, \boldsymbol{C}$, In the absence of primary antibody, cone and rod cells had no staining. $\mathbf{D}-\mathbf{G}$, Cone and rod cells, with either the sGC- $\alpha$ or sGC- $\beta$ antibody, had staining in the soma around the ellipsoid and in newly developed varicosities (arrows). $\boldsymbol{E}$, Inset, Fluorescent label for rod opsin is shown. $\boldsymbol{B}-\boldsymbol{E}$, Nomarski optics; $\boldsymbol{F}, \boldsymbol{G}$, bright-field optics. Scale bar, $10 \mu \mathrm{m}$.

Table 1. Effects of the NO donor SNAP (100 $\mu \mathrm{m})$ on the process outgrowth and varicosity formation of cone and rod cells cultured for $3 \mathrm{~d}$

\begin{tabular}{lrrrr}
\hline Categories & Control & SNAP treated & Percentage change & $t$ test $(p$ value) \\
\hline Cone & & & & \\
$\quad$ Cells analyzed & 100 & 100 & & \\
Total processes & 386 & 562 & $+45.6 \%$ & $<0.001$ \\
$1^{\circ}$ processes & 293 & 411 & $+40.3 \%$ & $<0.001$ \\
$2^{\circ}$ processes & 83 & 134 & $+61.4 \%$ & 0.006 \\
$3^{\circ}$ processes & 10 & 17 & $+70.0 \%$ & \\
Lamellipodia & 7 & 9 & $+28.6 \%$ & \\
Thick processes & 123 & 170 & $+38.2 \%$ & 0.004 \\
Thin processes & 163 & 232 & $+42.3 \%$ & 0.004 \\
$\quad$ Varicosities & 129 & 241 & $+86.8 \%$ & $<0.001$ \\
Rod & & & & \\
Cells analyzed & 100 & 100 & & \\
Total processes & 1415 & 1135 & $-19.8 \%$ & 0.037 \\
$1^{\circ}$ processes & 1146 & 888 & $-22.5 \%$ & 0.022 \\
$2^{\circ}$ processes & 233 & 218 & $-6.4 \%$ & \\
$3^{\circ}$ processes & 36 & 29 & $-19.4 \%$ & \\
Lamellipodia & 8 & 5 & $-37.5 \%$ & \\
Thick processes & 133 & 78 & $-41.4 \%$ & 0.014 \\
Thin processes & 1005 & 805 & $-19.9 \%$ & \\
Varicosities & 312 & 177 & $-43.3 \%$ & 0.004 \\
\hline
\end{tabular}

Rod cells labeled with 4D2 antibody were viewed with fluorescence microscopy, whereas cone cells were viewed with phase-contrast microscopy.

neural retinas. The antibody against the $\alpha$-subunit of sGC stained a band at $68 \mathrm{kDa}$, whereas the antibody against the $\beta$-subunit stained a band of $63 \mathrm{kDa}$ (Fig. $2 A$ ). These weights are lower than those reported for mammals; however, molecular weights for the $\alpha$ - and $\beta$-subunits vary depending on species and tissue of origin (Hobbs, 1997).

In $3 \mathrm{~d}$ cultures, HRP staining from either the $\alpha$ - or $\beta$-subunit antibody was present in all cell types with lowest intensities in Müller cells. In photoreceptors, staining occurred mainly in the soma and inner segment (the cytoplasm around the ellipsoid) of photoreceptors. In some cells, staining was also observed in the varicosities along the neuritic processes. Cone and rod cells were equally stained (Fig. $2 D-G$ ). Thus, both photoreceptor cell classes contained sGC, in contrast to a previous report in which sGC was found only in cone cells (Haberecht et al., 1998). The previous study, however, was not only in a different species but designed to detect only the $\alpha 1$ subunit, which could be less broadly distributed than the $\alpha 2$ or the $\beta$ subunit. In photoreceptors cultured for $2 \mathrm{~h}$, similar staining was observed, but the staining was weaker than that in 3-d-old photoreceptors (data not shown), indicating that the expression of sGC in cultured photoreceptors is upregulated with time. The upregulation of sGC expression may form the molecular basis for the continuous activity of the NO-cGMP signaling pathway observed in cultured retinal cells. In addition, it should be noted that because all cells had sGC staining, they all contributed to the cGMP levels determined by RIA.

\section{Activation or inhibition of soluble guanylyl cyclase}

The benzylindazole derivative $\mathrm{YC}-1$ is an allosteric activator of sGC (Ko et al., 1994). In the presence of NO, YC-1 synergistically increases the catalytic activity of sGC (Friebe and Koesling, 1998; Lamothe et al., 2004). A commonly used inhibitor of SGC is ODQ, which probably acts by oxidizing the heme group of the enzyme. Although the selectivity of ODQ at high concentrations has been questioned, moderate concentrations of ODQ are thought to selectively inhibit sGC (Garthwaite et al., 1995). With the immunocytochemical evidence that cultured photoreceptors contain $\mathrm{sGC}$, we investigated the effects of activation of SGC by YC- 1 or inhibition by ODQ on the structural plasticity of photoreceptors.

First, $50 \mu \mathrm{M}$ ODQ was applied to the cultures, and cells were maintained for $3 \mathrm{~d}$. These experiments were done either with or without an inhibitor of PDE, $1 \mathrm{mM}$ IBMX. Inhibition of cGMP hydrolysis ensured that low amounts of cGMP would be detectable by radioimmunoassay; cultures without IBMX were examined to ensure that the PDE inhibitor itself did not distort the overall effect of ODQ. RIA showed that cGMP levels decreased significantly in the lysate of retinal cells treated with ODQ (78.9 \pm 6.1 vs $92.5 \pm 5.8$ fmol per 200 cells). This decrease in cGMP synthesis, compared with control cells, was more obvious when degradation of cGMP was prevented with IBMX (360.9 \pm 33.8 vs $486.1 \pm 40.7$ fmol per 200 cells) (Fig. $3 A$ ). Thus, $50 \mu \mathrm{M}$ ODQ effectively inhibited sGC and decreased cGMP production for a period of up to $3 \mathrm{~d}$. Next, $1 \mu \mathrm{M}$ YC-1 was applied to cultures, and cells were maintained for 1 or $3 \mathrm{~d}$ in the presence of $1 \mathrm{~mm}$ IBMX. RIA showed that the cGMP content in the lysate of retinal cells cultured with $1 \mu \mathrm{M}$ YC- 1 for $1 \mathrm{~d}$ was significantly higher than that in control retinal cells $(618.5 \pm 31.1$ vs $359.5 \pm 14.5 \mathrm{fmol}$ per 200 cells); the cGMP content was also higher after $3 \mathrm{~d}$ of culture than control $(639.3 \pm 35.1$ vs $480.6 \pm 13.0 \mathrm{fmol}$ per 200 cells) (Fig. $3 B$ ). Thus, $1 \mu \mathrm{M}$ YC-1 effectively increased cGMP production.

To investigate how inhibition of sGC affects regenerative growth of photoreceptors, three concentrations $(0.5,5$, and 50 $\mu \mathrm{M})$ of ODQ were added to cultures, and photoreceptors were grown for $3 \mathrm{~d}$. In cone cells, ODQ caused a dose-dependent decrease in the number of neuritic processes and varicosities that 
was significant only for the reduction in the number of processes (Fig. 3C). Using $50 \mu \mathrm{M}$ ODQ, the experiment was repeated twice more. With a larger $n$, significant decreases in both the number of neuritic processes $(34.6 \%)$ and varicosities $(33.6 \%)$ in cone cells were observed (Fig. 3D). In rod cells, 0.5 and $5 \mu \mathrm{M}$ ODQ caused no change in the growth of the neuritic structures. However, at the highest concentration, 50 $\mu \mathrm{M}, \mathrm{ODQ}$ caused unexpected and significant decreases in the number of neuritic processes and varicosities (46.5 and $40.9 \%$, respectively; data not shown). Although $50 \mu \mathrm{M}$ ODQ did not cause an obvious decrease in cell density in 3-d-old cultures (data not shown), it is possible that the highest concentration of ODQ may have had nonspecific effects on other signaling transduction mechanisms in rod cells.

To activate sGC, three concentrations $(1,10$, and $100 \mu \mathrm{M})$ of YC- 1 were applied to cultures for $3 \mathrm{~d}$. In cone cells, $1 \mu \mathrm{M}$ YC- 1 caused a significant increase in the number of neuritic processes $(31.2 \%)$ and varicosities (59.2\%). Higher concentrations (10 and $100 \mu \mathrm{M}$ ) of YC-1, however, did not cause additional increases in neuritic development. Instead, the highest dose caused a significant decrease in processes and varicosities (Fig. $3 E$ ). In rod cells, YC-1 caused a dose-dependent decrease in the number of neuritic processes and varicosities. The application of 1,10 , and $100 \mu \mathrm{M}$ YC- 1 caused $9.8,16.4$, and $62.2 \%$ decreases, respectively, in the number of neuritic processes and 21.2, 20.7, and 46.8\% decreases, respectively, in the number of varicosities. Only the decreases caused by $100 \mu \mathrm{M}$ YC-1 were statistically significant in rod cells (Fig. $3 F$ ).

In summary, the above results show that activation of sGC with YC-1 or inhibition with ODQ effectively increased and decreased cGMP production, respectively, by cultured retinal cells. The activation of sGC with YC-1 at low concentration significantly stimulated the neuritic sprouting and varicosity formation by cone cells, whereas the highest YC-1 concentration had an inhibitory effect on neuritic growth. In rod cells, the activation of sGC with YC-1 caused a consistent dose-dependent inhibition of the neurite sprouting and varicosity formation. On the other hand, the inhibition of sGC with ODQ caused an inhibition of the neuritic growth by cone cells; for rod cells, at low concentrations there was no effect. Thus, cone and rod cells responded differently toward the activation or inhibition of sGC.

\section{Targets of cGMP}

cGMP activates a variety of target molecules including cGMPgated channels, protein kinases, and cGMP-dependent phosphodiesterases. $8 \mathrm{Br}$-cGMP, a membrane-permeant analog of cGMP, was used to mimic the activities of the endogenous NOcGMP signaling pathway.

Three concentrations ( $35 \mu \mathrm{M}, 350 \mu \mathrm{M}$, and $1.4 \mathrm{~mm}$ ) of $8 \mathrm{Br}-$ cGMP were added to cultures, and photoreceptors were grown for 3 d. Previously, we had investigated the effects of 8Br-cGMP on the varicosity formation by cone and rod cells and found that $350 \mu \mathrm{M} 8 \mathrm{Br}-\mathrm{cGMP}$ but not $35 \mu \mathrm{M}$ or $1.4 \mathrm{~mm} 8 \mathrm{Br}-\mathrm{cGMP}$ could significantly increase the number of varicosities in cone cells; in
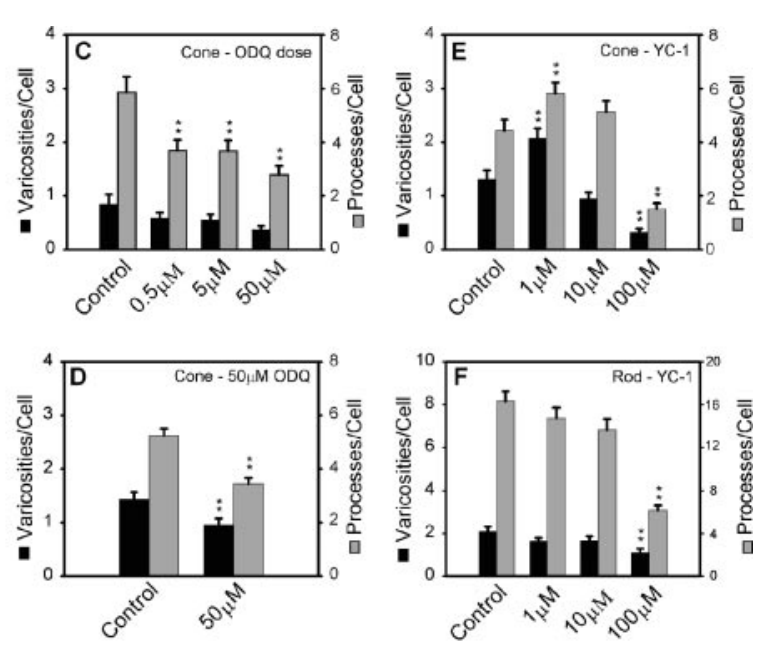

Figure 3. The $S G C$ inhibitor $O D Q$ decreased cone growth, whereas the $S G C$ activator $Y C-1$ increased growth in cone cells but

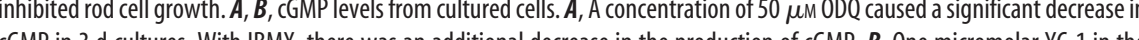
processes and varicosities. $\boldsymbol{A}, \boldsymbol{B}, n=8$ cultures from two animals; $\boldsymbol{C}, n=200$ cells in eight culture dishes from one animal; $\boldsymbol{D}, n=$ 300 cells in six culture dishes from three animals; $\boldsymbol{E}, \boldsymbol{F}, n=800$ cells in 16 culture dishes from three animals. ${ }^{*} p<0.05 ;{ }^{* *} p<$

rod cells, however, 8Br-cGMP caused a dose-dependent decrease in the number of varicosities (Zhang and Townes-Anderson, 2002). In the present series of experiments, the number of neuritic processes and the length of the longest processes from those photoreceptors were also analyzed. Data from processes and varicosities have been combined (Fig. 4E,F); changes in process length followed the pattern for number of processes and have not been included. In cone cells (Fig. $4 E$ ), $35 \mu \mathrm{M} 8 \mathrm{Br}$-cGMP caused a significant increase in the number of neuritic processes by $67.6 \%$. Three hundred fifty micromolar 8Br-cGMP caused additional significant increases in both the number of neuritic processes (79.2\%) and varicosities (80.0\%) (Fig. 4A,C). The highest concentration (1.4 mM) of 8Br-cGMP, however, caused no significant increases in growth. In rod cells (Fig. $4 B, D, F$ ), all concentrations of $8 \mathrm{Br}-\mathrm{cGMP}$ caused a significant decrease in the number of varicosities, and at $1.4 \mathrm{~mm}$ there was also a significant decrease in the number of processes. There was no significant decrease in cell density of retinal cultures treated with $1.4 \mathrm{mM}$ 8Br-cGMP (data not shown). Thus, 8Br-cGMP, at $350 \mu \mathrm{M}$, significantly stimulated neuritic sprouting and varicosity formation by cone cells; in rod cells, however, 8Br-cGMP caused a dosedependent inhibition of neuritic growth. As with SNAP, detailed analysis of growth revealed that many types of growth were stimulated in cone cells by $8 \mathrm{Br}-\mathrm{cGMP}$ (Table 2 ). In contrast, inhibition of growth by $8 \mathrm{Br}-\mathrm{cGMP}$ in rod cells was not as broad as SNAP.

cGMP-gated channels, one of the targets for cGMP, have been shown to be necessary for structural plasticity by cone cells (Zhang and Townes-Anderson, 2002), presumably by opening to allow $\mathrm{Ca}^{2+}$ influx into the synaptic terminal (Rieke and Schwartz, 1994). To investigate the role of cGMP-gated channels in process and varicosity formation, $350 \mu \mathrm{M} 8 \mathrm{Br}-\mathrm{cGMP}$ and 100 $\mu \mathrm{M}$ Lcd, a cGMP-gated channel blocker that also has affinity for L-type channels (Ikeda et al., 1991), were added to cultures for 

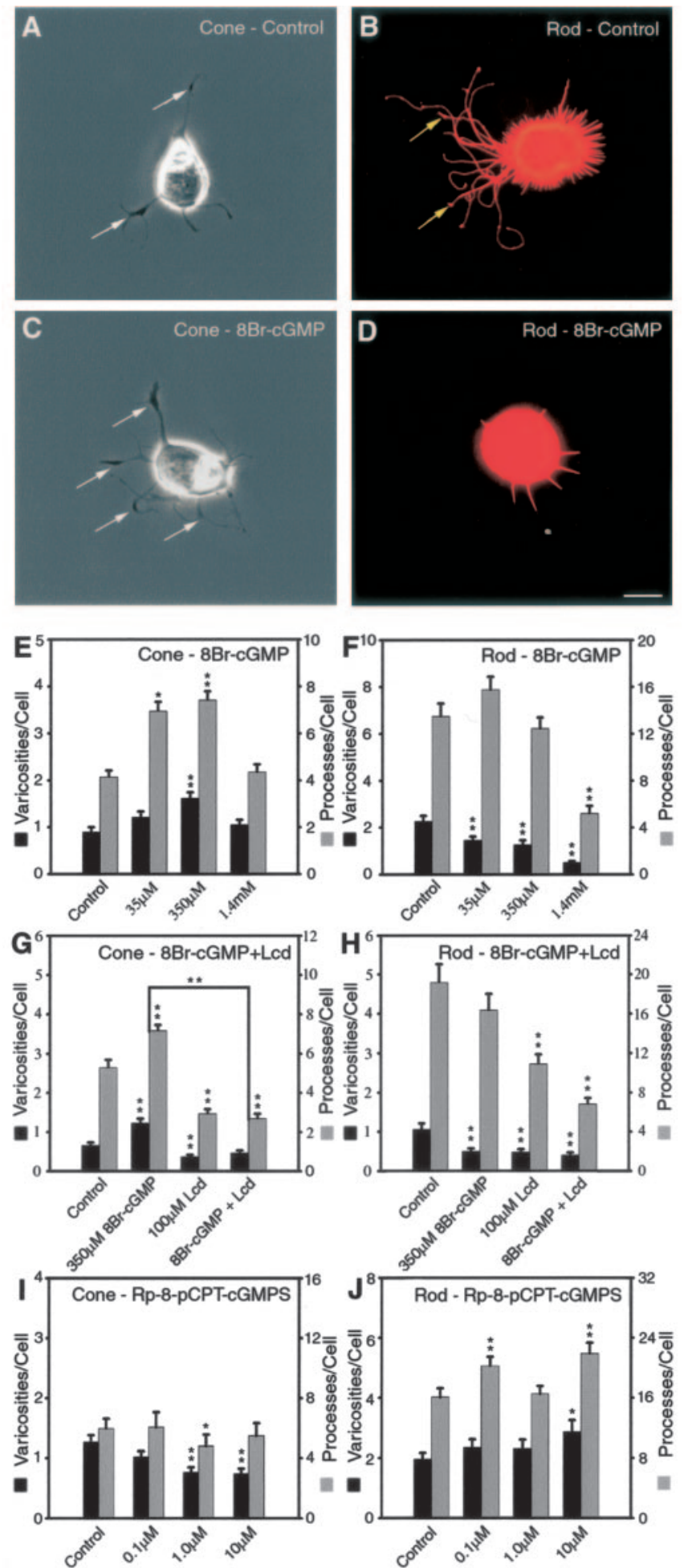

Figure 4. Growth of photoreceptors treated with cGMP analogs and the $\mathrm{Ca}^{2+}$ channel blocker Lcd are shown. Cone and rod cells show opposite growth patterns, although blocking calcium influx affects both cell types. $\boldsymbol{A}$, An untreated cone cell in phase-contrast optics. Neuritic processes with branching structures as well as vesicle-containing varicosities (arrows) can be observed. $\boldsymbol{B}$, An untreated rod cell labeled for rod opsin seen with fluorescence microscopy. There is abundant outgrowth of neuritic processes with varicosities (arrows) formed along the thicker processes. C, A cone cell treated with $8 \mathrm{Br}$-cGMP (350 $\mu \mathrm{M})$ shows more varicosities (arrows) along neuritic processes than the control cell. $D$, A rod cell treated with $8 \mathrm{Br}$-cGMP (350 $\mu \mathrm{m})$ has fewer processes and no varicosities. $\boldsymbol{A}-\boldsymbol{D}$, Cells were from $3 \mathrm{~d}$ cultures. Scale bar, 10 $\mu \mathrm{m}$. $\boldsymbol{E}-\boldsymbol{J}$, Quantitative analysis of process outgrowth and varicosity formation after $3 \mathrm{~d}$ of treatment. $\boldsymbol{E}$, For cone cells, $350 \mu \mathrm{m} 8 \mathrm{Br}$-cGMP caused a more significant increase in the
Table 2. Effects of the CGMP analog 8Br-cGMP ( $350 \mu \mathrm{m})$ on the process outgrowth and varicosity formation of cone and rod cells cultured for $3 \mathrm{~d}$

\begin{tabular}{lrrcr}
\hline Categories & Control & 8Br-cGMP & Percentage change & $t$ test ( $p$ value) \\
\hline Cone & & & & \\
$\quad$ Cells analyzed & 100 & 100 & & $<0.001$ \\
Total processes & 414 & 712 & $+71.9 \%$ & $<0.001$ \\
$1^{\circ}$ processes & 290 & 411 & $+41.7 \%$ & $<0.001$ \\
$2^{\circ}$ processes & 105 & 268 & $+155.3 \%$ & \\
$3^{\circ}$ processes & 19 & 33 & $+46.2 \%$ & 0.003 \\
Lamellipodia & 13 & 19 & $+46.1 \%$ & $<0.001$ \\
Thick processes & 176 & 236 & $+34.1 \%$ & $<0.001$ \\
Thin processes & 101 & 186 & $+84.2 \%$ & \\
Varicosities & 90 & 162 & $+80.0 \%$ & \\
Rod & & & & \\
Cells analyzed & 100 & 100 & & \\
Total processes & 1348 & 1244 & $-7.7 \%$ & \\
$1^{\circ}$ processes & 816 & 819 & $+0.4 \%$ & \\
$2^{\circ}$ processes & 463 & 371 & $-19.5 \%$ & \\
$3^{\circ}$ processes & 69 & 54 & $-21.7 \%$ & \\
Lamellipodia & 19 & 24 & $+26.3 \%$ & \\
Thick processes & 215 & 216 & $+0.5 \%$ & $-0.5 \%$ \\
Thin processes & 582 & 579 & $-44.2 \%$ & \\
Varicosities & 226 & 126 & & \\
\hline
\end{tabular}

Rod cells labeled with $4 \mathrm{D} 2$ antibody were viewed with fluorescence microscopy, whereas cone cells were viewed with phase-contrast microscopy.

$3 \mathrm{~d}$. In cone cells (Fig. 4G), $350 \mu \mathrm{M} 8 \mathrm{Br}$-cGMP alone caused significant increases in the number of neuritic processes and varicosities, consistent with the results described above. After the application of $100 \mu \mathrm{M} \mathrm{Lcd} \mathrm{alone,} \mathrm{there} \mathrm{was} \mathrm{a} \mathrm{decrease} \mathrm{in} \mathrm{the}$ number of neuritic processes $(44.9 \% ; p<0.001)$ and varicosities (44.6\%; $p=0.004)$, consistent with previous results (Zhang and Townes-Anderson, 2002). In the presence of $100 \mu \mathrm{M} \mathrm{Lcd,} 350 \mu \mathrm{M}$ $8 \mathrm{Br}-\mathrm{cGMP}$ no longer caused an increase in the number of neuritic processes or varicosities. There was a $62.7 \%$ decrease in the number of neuritic processes $(p<0.001)$ and a $63.1 \%$ decrease in the number of varicosities $(p<0.001)$ in cone cells treated with $8 \mathrm{Br}$-cGMP and Lcd simultaneously compared with cone cells treated with $8 \mathrm{Br}-\mathrm{cGMP}$ alone. Blockage of cGMP-gated and L-type channels, therefore, completely abolished the ability of 8Br-cGMP to stimulate cone growth (Fig. 4G). Previous work has shown that blockage of L-type channels by nicardipine caused very little change, only inhibition of tertiary branches, in cone cells (Zhang and Townes-Anderson, 2002). The effect induced by Lcd, therefore, may be caused primarily by blockage of $\mathrm{Ca}^{2+}$ influx through cGMP-gated channels. In rod cells (Fig. 4H), L-type $\mathrm{Ca}^{2+}$ channels were required for structural plasticity, but previous work reported that Lcd also inhibited varicosity formation (Nachman-Clewner et al., 1999; Zhang and TownesAnderson, 2002). Here, we again observed that Lcd inhibited the neuritic growth of rod cells. Lcd inhibits rod cells presumably

$\leftarrow$

number of processes and varicosities than $35 \mu \mathrm{M} 8 \mathrm{Br}$-cGMP. However, the highest concentration of 8Br-cGMP did not cause an increase. $F$, Rod cells treated with 8Br-cGMP had a dosedependent inhibition in the number of varicosities; however, only the highest concentration of $8 \mathrm{Br}$-cGMP caused a significant decrease in the number of processes. $\mathbf{G}$, In cone cells, Lcd completely abolished the stimulatory effect of $350 \mu \mathrm{m} 8 \mathrm{Br}$-cGMP. $\boldsymbol{H}$, In rod cells, Lcd furthered the inhibitory effects of $350 \mu \mathrm{M} 8 \mathrm{Br}$-cGMP to cause a significant decrease in the number of processes and varicosities. I, Cone cells treated with the PKG inhibitor Rp-8-pCPT-cGMPS had significant decreases in the numbers of processes and varicosities. J, Rod cells treated with Rp-8pCPT-cGMPS had significant increases in growth. $\boldsymbol{E}, \boldsymbol{F}, n=800$ cells in 16 culture dishes from three animals; $\boldsymbol{G}, \boldsymbol{H}, n=800$ cells in 16 culture dishes from two animals; $\boldsymbol{I}, \boldsymbol{J}, n=800$ cells in 16 culture dishes from two animals. ${ }^{*} p<0.05 ;{ }^{* *} p<0.001$. Error bars represent + SEM. 
because Lcd can affect L-type $\mathrm{Ca}^{2+}$ channels (Ikeda et al., 1991). Simultaneous application of Lcd and 8Br-cGMP further reduced rod cell growth (Fig. $4 G$ ).

PKG is another well identified target for cGMP. The PKG inhibitor Rp-8-pCPT-cGMPS (Butt et al., 1994) was added to cultures, and photoreceptors were maintained for $3 \mathrm{~d}$. In cone cells, 1 and $10 \mu \mathrm{M}$ Rp-8-pCPT-cGMPS caused obvious decreases in the amount of growth; the number of neuritic processes decreased by $17.7 \%$ at $1 \mu \mathrm{M}(p=0.038)$, and the number of varicosities decreased significantly by 50 and $42 \%$ at 1 and $10 \mu \mathrm{M}$, respectively (Fig. $4 I$ ). In rod cells, 0.1 and $10 \mu \mathrm{M} \mathrm{Rp-8-pCPT-}$ cGMPS caused significant increases in the number of neuritic processes and, at $10 \mu \mathrm{M}$, a $47 \%$ increase in varicosities $(p=$ 0.026 ) (Fig. $4 J$ ).

In summary, activation of downstream targets of the NOcGMP signaling pathway with the cGMP analog 8Br-cGMP confirmed the results of the previous sections that stimulation of cone neuritic sprouting and varicosity formation occurs at certain increased levels of cGMP, whereas inhibition of rod cell growth occurs at the same, increased concentrations of cGMP (supplemental Fig. 2, available at www.jneurosci.org as supplemental material). In cone cells, the activation of the NO-cGMP signaling pathway may stimulate process sprouting in part by increasing $\mathrm{Ca}^{2+}$ influx through cGMP-gated channels and in part by phosphorylation of unknown targets by PKG. In rod cells, inhibition of growth through the activation of the NO-cGMP signaling pathway appears to require phosphorylation by PKG. Reduction in $\mathrm{Ca}^{2+}$ influx will also reduce growth (Fig. $4 \mathrm{H}$ ). Although cGMP does not directly interact with L-type channels in rod cells, an indirect inhibitory effect of cGMP via PKG on these channels is possible.

\section{Discussion}

Structural synaptic plasticity in the form of axonal retraction, neurite growth, and varicosity formation are well documented reactions by photoreceptors in response to injury and disease such as retinal detachment and retinitis pigmentosa ( $\mathrm{Li}$ et al., 1995; Fisher and Lewis, 2003; Marc et al., 2003). These reactions, seen in the adult mammalian and human retina, are duplicated in isolated, adult salamander photoreceptors that are either denervated or axotomized (Mandell et al., 1993; Nachman-Clewner and Townes-Anderson, 1996). Retraction in rod cells can be controlled by blocking $\mathrm{Ca}^{2+}$ channels (Nachman-Clewner et al., 1999), whereas neurite outgrowth and varicosity formation in cone and rod cells is dependent in part on functional $\mathrm{Ca}^{2+}$ channels, cGMP-gated channels in cone cells, and L-type channels in rod cells (Zhang and Townes-Anderson, 2002). Here, we have shown that neuritic sprouting and varicosity formation can be stimulated or inhibited in cone and rod cells, respectively, by cGMP. We have compared levels of NO and cGMP with a quantitative examination of growth and assessed the dose dependency of growth for each reagent used in this study. Although intracellular levels within individual cell types are not known for every concentration of reagent, two general principles of cGMP signaling are apparent: (1) the level of cGMP is an important determinant of the amount of growth, and (2) cone and rod cells do not respond the same way (i.e., increasing versus decreasing growth) to the same activation or inhibition of NO-cGMP signaling.

In cone cells, reduction in cGMP or NO synthesis, by ODQ and L-NAME, respectively, or blockage of the cGMP targets cGMP-gated channels or PKG, by Lcd and a cGMP analog, respectively, reduced growth. Increases in cGMP, by sGC activators YC-1 or SNAP, or by $8 \mathrm{Br}-\mathrm{cGMP}$, caused increased growth at moderate levels of stimulation; higher levels of cGMP resulted in a reversion back to normal growth and even a significant reduction in growth (in the case of $100 \mu \mathrm{M}$ YC-1). Thus, there is a bell-shaped curve in the growth response (supplemental Fig. $2 \mathrm{~A}$, available at www.jneurosci.org as supplemental material). This result is consistent with a cGMP dose dependency of growth cone turning in developing Xenopus spinal cord neurons (Nishiyama et al., 2003) and neurite growth in snail B5 neurons (Trimm and Rehder, 2004). A possible explanation for a bell-shaped doseresponse is the presence of a feedback loop in which increased cGMP results in negative feedback regulation of cGMP concentration. In cerebellar Purkinje cells, PDE5 activity is stimulated by PKG phosphorylation when the NO-cGMP pathway is active, whereas it becomes less active at low levels of cGMP (ShimizuAlbergine et al., 2003), providing negative feedback to control cGMP levels. Viagra, a PDE5 inhibitor, has effects on retinal activity including outer retinal function (Jägle et al., 2004). PDE5 is not known to be present in photoreceptors, but its presence or some similar enzyme activity may provide the negative feedback to explain the cone cell growth profile.

In rod cells, activation of the NO-cGMP pathway caused a linear, dose-dependent reduction in growth (supplemental Fig. $2 B$, available at www.jneurosci.org as supplemental material). Reduction in cGMP or NO, by ODQ and L-NAME, respectively, or in PKG activity by a cGMP analog, caused either no change or an increase in growth. It is possible that in rod cells intracellular levels of cGMP are intrinsically higher than in cone cells so that any additional increase in NO-cGMP signaling was inhibitory. We have some evidence, however, that cAMP can stimulate rod cell growth (Townes-Anderson et al., 2003), and thus the signaling system mediating rod cell neuritic growth and varicosity formation may not depend primarily on cGMP. This would be consistent with the presence of cGMP-gated channels in cone but not in rod synaptic terminals (Rieke and Schwartz, 1994).

Additional differences in intracellular signaling between cone and rod cells undoubtedly contribute to the differential responses of these sensory neurons to NO-cGMP. In the snail, nerve cells B5 and B19 show growth and no growth, respectively, in response to cGMP (Van Wagenen and Rehder, 2001), and in rat cortical neurons, pyramidal dendrites and axons grow toward and away from the pial surface, respectively (Polleux et al., 2000), depending on the presence or absence of sGC. We have demonstrated, however, that both cone and rod cells contain sGC, and no obvious differences in amount or location were noted. As suggested above, differences in the number, type, and/or location of PDEs in cone and rod cells are possible but as yet untested. PKGs of cone and rod cells may be different as well. In brain, PKG I and II are rarely found in the same cell (Pfeifer et al., 1999). As mentioned previously, cGMP can enhance $\mathrm{Ca}^{2+}$ influx in salamander cone pedicles (Rieke and Schwartz, 1994) but not in rod cells, and $\mathrm{NO}$, working through cGMP and cGMP-gated channels, leads to a calcium-induced increase of neurotransmitter release from cones (Savchenko et al., 1997). Cone cells also contain L-type channels in their terminals. The cone and rod L-type channel isoforms, however, are different (Morgans, 1999, 2001); in addition, in salamander, there may be fewer L-type channels in cone than rod terminals (Nachman-Clewner et al., 1999). Differences in the molecular mechanisms of $\mathrm{Ca}^{2+}$ homeostasis between cone and rod cells have also been reported. For instance, plasma membrane $\mathrm{Ca}^{2+}$-ATPase, present in cone and rod terminals (Morgans et al., 1998), can extrude $\mathrm{Ca}^{2+}$, released from intracellular stores, more rapidly in cone than rod cells (Krizaj et al., 2003). $\mathrm{Ca}^{2+}$ in turn can affect some PDEs (Beavo, 1995) and the synthesis of 
cGMP from particulate and soluble GC (Pugh et al., 1997; Margulis and Sitaramayya, 2000), both of which are present in synaptic terminals (Cooper et al., 1995; this paper). Moreover, $\mathrm{Ca}^{2+}$-binding cofactors for pGC, guanylyl cyclase-activating protein 1 and 2, are distributed unequally between cone pedicles and rod spherules in mammalian retina (Cuenca et al., 1998). Thus, differences in the molecular components of nucleotide and $\mathrm{Ca}^{2+}$ signaling pathways may both play a role in the differential responses of cone and rod synaptic endings to injury.

Additional differences between cone and rod cells may depend on the activity of NO. In addition to phosphorylation through PKG, NO causes $S$-nitrosylation of proteins and reacts with superoxide to form peroxynitrate, leading to oxidation. In other nerve cell types, these activities result in differing growth responses (Cheung et al., 2000). In salamander photoreceptors, the NO donor $S$-nitrosocysteine decreases L-type $\mathrm{Ca}^{2+}$ channel current in cone but increases current in rod cells, presumably because of $S$-nitrosylation (Kurenny et al., 1994; Kourennyi et al., 2004). In contrast, the use of SNAP as an NO donor in our cultures in the presence of SOD and catalase has been suggested to favor phosphorylation and closure of rod cell L-type channels (Liu and Kourennyi, 2004). In culture, rod cells showed less inhibition of process outgrowth with the cGMP analog 8Br-cGMP than with SNAP. cGMP generated by SNAP might be especially effective at reducing $\mathrm{Ca}^{2+}$ current, because activation of endogenous sGC increases cGMP at specific sites as opposed to a more diffuse presence of cGMP when using a membrane-permeable ana$\log$. Moreover, SNAP, through S-nitrosylation of unknown targets, may have produced additional inhibitory effects on rod growth.

The present results on cGMP have implications for the autosomal recessive form of RP associated with defects in rod PDE6. That activation of NO-cGMP signaling caused an increase in growth of cone cells, but a decrease in growth of rod cells is consistent with the reports on $\mathrm{rdl}$ mouse retina that showed exuberant cone cell sprouting but a lack of rod cell growth (Blanks et al., 1974; Fei, 2002). In the rod-cone dysplasia 1 canine retina, cGMP concentration is also increased (Aquirre et al., 1978), but synaptic morphology has not yet been examined. For the diseased mouse retina, an increase of cGMP in rod cells is easily envisioned, because mutant rod PDE6 with defective $\beta$ subunits is assumed to be unable to hydrolyze cGMP. In contrast, cone PDE is intact, because it is made up of $\alpha^{1}$ subunits and not known to carry disease-associated mutations (Gao et al., 1999). Increases in cGMP in cone cells, however, could come through the gap junctions known to be present between rod and cone synaptic terminals (Raviola and Gilula, 1973). It is possible that abnormalities in the electroretinogram of human patients in the early stages of RP are caused by cGMP-induced synaptic remodeling (Banin et al., 1999). Because NOS stimulation occurs in nervous tissue injury in general (Yun et al., 1996), it will be of interest to determine the degree of structural synaptic change in other CNS traumas and degenerative diseases as well and the cell-specific molecular mechanisms associated with these injury/ disease responses.

Mechanisms involved in the synaptic responses to insult in the retina are beginning to be worked out. The involvement of cGMP in cone and rod structural plasticity indicates that there is some commonality in the mechanisms used by neurons during development, during activity-dependent plasticity, in which NOcGMP signaling plays a role in long-term potentiation and longterm depression (Zhuo et al., 1994; Holscher, 1997) and now in injury. At the same time, it is clear that the details of the mechanisms will be event and cell-type specific.

\section{References}

Aggarwal BB, Mehta K (1996) Determination and regulation of nitric oxide production from macrophages by lipopolysaccharides, cytokines, and retinoids. Methods Enzymol 269:166-171.

Ahmad I, Barnstable CJ (1993) Differential laminar expression of particulate and soluble guanylate cyclase genes in rat retina. Exp Eye Res 56:51-62.

Aquirre G, Farber D, Lolley R, Fletcher RT, Chader GJ (1978) Rod-cone dysplasia in Irish setters: a defect in cyclic GMP metabolism in visual cells. Science 22:1133-1134.

Banin E, Cideciyan AV, Aleman TS, Petters RM, Wong F, Milam AH, Jacobson SG (1999) Retinal rod photoreceptor-specific gene mutation perturbs cone pathway development. Neuron 23:549-557.

Beavo JA (1995) Cyclic nucleotide phosphodiesterases: functional implications of multiple isoforms. Physiol Rev 75:725-748.

Blanks JC, Adinolfi AM, Lolley RN (1974) Photoreceptor degeneration and synaptogenesis in retinal-degenerative (rd) mice. J Comp Neurol 156:95-106.

Boer R, Ulrich W-R, Klein T, Mirau B, Haas S, Baur I (2000) The inhibitory potency and selectivity of arginine substrate site nitric-oxide synthase inhibitors is solely determined by their affinity toward the different isoenzymes. Mol Pharmacol 58:1026-1034.

Bradford MM (1976) A rapid and sensitive method for the quantitation of microgram quantities of protein utilizing the principle of protein-dye binding. Anal Biochem 72:248-254.

Butt E, Eigenthaler M, Genieser HG (1994) (Rp)-8-pCPT-cGMPS, a novel cGMP-dependent protein kinase inhibitor. Eur J Pharmacol 269:265-268.

Cheung WS, Bhan I, Lipton SA (2000) Nitric oxide (NO.) stabilizes whereas nitrosonium $(\mathrm{NO}+$ ) enhances filopodial outgrowth by rat retinal ganglion cells in vitro. Brain Res 868:1-13.

Cooper N, Liu L, Yoshida A, Pozdnyakov N, Margulis A, Sitaramayya A (1995) The bovine rod outer segment guanylate cyclase, ROS-GC, is present in both outer segment and synaptic layers of the retina. J Mol Neurosci 6:211-222.

Cuenca N, Lopez S, Howes K, Kolb H (1998) The localization of guanylyl cyclase-activating proteins in the mammalian retina. Invest Ophthalmol Vis Sci 39:1243-1250.

Domino SE, Tubb DJ, Garbers DL (1991) Assay of guanylyl cyclase catalytic activity. Methods Enzymol 195:345-355.

Farber DB, Lolley RN (1974) Cyclic guanosine monophosphate: elevation in degenerating photoreceptor cells of the $\mathrm{C} 3 \mathrm{H}$ mouse retina. Science 186:449-451.

Fei Y (2002) Cone neurite sprouting: an early onset abnormality of the cone photoreceptors in the retinal degeneration mouse. Mol Vis 8:306-314.

Fisher SK, Lewis GP (2003) Muller cell and neuronal remodeling in retinal detachment and reattachment and their potential consequences for visual recovery: a review and reconsideration of recent data. Vision Res 43:887-897.

Friebe A, Koesling D (1998) Mechanism of YC-1-induced activation of soluble guanylyl cyclase. Mol Pharmacol 53:123-127.

Gamm DM, Barthel LK, Raymond PA, Uhler MD (2000) Localization of cGMP-dependent protein kinase isoforms in mouse eye. Invest Ophthalmol Vis Sci 41:2766-2773.

Gao YQ, Danciger M, Longmuir R, Piriev NI, Zhao DY, Heckenlively JR, Fishman GA, Weleber RG, Jacobson SG, Stone EM, Farber DB (1999) Screening of the gene encoding the $\alpha$ 'subunit of cone cGMP-PDE in patients with retinal degenerations. Invest Ophthalmol Vis Sci 40:1818-1822.

Garthwaite J (1995) Neural nitric oxide signalling. Trends Neurosci $18: 51-52$.

Garthwaite J, Southam E, Boulton CL, Nielsen EB, Schmidt K, Mayer B (1995) Potent and selective inhibition of nitric oxide-sensitive guanylyl cyclase by $1 \mathrm{H}-[1,2,4]$ oxadiazolo[4,3-a] quinoxalin-1-one. Mol Pharmacol 48:184-188.

Haberecht MF, Schmidt HH, Mills SL, Massey SC, Nakane M, RedburnJohnson DA (1998) Localization of nitric oxide synthase, NADPH diaphorase and soluble guanylyl cyclase in adult rabbit retina. Vis Neurosci 15:881-890.

Hicks D, Molday RS (1986) Differential immunogold-dextran labeling of bovine and frog rod and cone cells using monoclonal antibodies against bovine rhodopsin. Exp Eye Res 42:55-71. 
Hobbs AJ (1997) Soluble guanylate cyclase: the forgotten sibling. Trends Pharmacol Sci 18:484-491.

Holscher C (1997) Nitric oxide, the enigmatic neuronal messenger: its role in synaptic plasticity. Trends Neurosci 20:298-303.

Ikeda S, Oka J, Nagao T (1991) Effects of four diltiazem stereoisomers on binding of D-cis- $[3 \mathrm{H}]$ diltiazem and $(+)-[3 \mathrm{H}] \mathrm{PN} 200-110$ to rabbit T-tubule calcium channels. Eur J Pharmacol 208:199-205.

Jägle H, Jägle C, Sérey L, Yu A, Rilk A, Sadowski B, Besch D, Zrenner E, Sharpe LT (2004) Visual short-term effects of Viagra: double-blind study in healthy young subjects. Am J Ophthalmol 137:842-849.

Ko FN, Wu CC, Kuo SC, Lee FY, Teng CM (1994) YC-1, a novel activator of platelet guanylate cyclase. Blood 84:4226-4233.

Kourennyi DE, Liu X, Hart J, Mahmud F, Baldridge WH, Barnes S (2004) Reciprocal modulation of calcium dynamics at rod and cone photoreceptor synapses by nitric oxide. J Neurophysiol 92:477-483.

Krizaj D, Lai FA, Copenhagen DR (2003) Ryanodine stores and calcium regulation in the inner segments of salamander rods and cones. J Physiol (Lond) 547:761-774.

Kurenny DE, Moroz LL, Turner RW, Sharkey KA, Barnes S (1994) Modulation of ion channels in rod photoreceptors by nitric oxide. Neuron 13:315-324.

Lamothe M, Chang FJ, Balashova N, Shirokov R, Beuve A (2004) Functional characterization of nitric oxide and YC-1 activation of soluble guanylyl cyclase: structural implication for the YC-1 binding site? Biochemistry 43:3039-3048.

Li ZY, Kljavin IJ, Milam AH (1995) Rod photoreceptor neurite sprouting in retinitis pigmentosa. J Neurosci 15:5429-5438.

Liepe BA, Stone C, Koistinaho J, Copenhagen DR (1994) Nitric oxide synthase in Müller cells and neurons of salamander and fish retina. J Neurosci 14:7641-7654.

Lipton SA, Choi YB, Pan ZH, Lei SZ, Chen HS, Sucher NJ, Loscalzo J, Singel DJ, Stamler JS (1993) A redox-based mechanism for the neuroprotective and neurodestructive effects of nitric oxide and related nitrosocompounds. Nature 364:626-632.

Liu X, Kourennyi DE (2004) D-S-nitrosocysteine inhibits the calcium channels in rod photoreceptors. Paper presented at Annual Meeting of Association for Research in Vision and Ophthalmology.

Liu X, Seno K, Nishizawa Y, Hayashi F, Yamazaki A, Matsumoto H, Wakabayashi T, Usukura J (1994) Ultrastructural localization of retinal guanylate cyclase in human and monkey retinas. Exp Eye Res 59:761-768.

MacLeish PR, Townes-Anderson E (1988) Growth and synapse formation among major classes of adult salamander retinal neurons in vitro. Neuron 1:751-760.

MacLeish PR, Barnstable CJ, Townes-Anderson E (1983) Use of a monoclonal antibody as a substrate for mature neurons in vitro. Proc Natl Acad Sci USA 80:7014-7018.

Mandell JW, MacLeish PR, Townes-Anderson E (1993) Process outgrowth and synaptic varicosity formation by adult photoreceptors in vitro. J Neurosci 13:3533-3548.

Marc RE, Jones BW, Watt CB, Strettoi E (2003) Neural remodeling in retinal degeneration. Prog Retin Eye Res 22:607-655.

Margulis A, Sitaramayya A (2000) Rate of deactivation of nitric oxidestimulated soluble guanylate cyclase: influence of nitric oxide scavengers and calcium. Biochemistry 39:1034-1039.

Miller MJ, Thompson JH, Liu X, Eloby-Childress S, Sadowska-Krowicka H, Zhang XJ, Clark DA (1996) Failure of L-NAME to cause inhibition of nitric oxide synthesis: role of inducible nitric oxide synthase. Inflamm Res 45:272-276.

Morgans CW (1999) Calcium channel heterogeneity among cone photoreceptors in the tree shrew retina. Eur J Neurosci 11:2989-2993.

Morgans CW (2001) Localization of the alpha(1F) calcium channel subunit in the rat retina. Invest Ophthalmol Vis Sci 42:2414-2418.

Morgans CW, El Far O, Berntson A, Wassle H, Taylor WR (1998) Calcium extrusion from mammalian photoreceptor terminals. J Neurosci 18:2467-2474.

Nachman-Clewner M, Townes-Anderson E (1996) Injury-induced remodelling and regeneration of the ribbon presynaptic terminal in vitro. J Neurocytol 25:597-613.

Nachman-Clewner M, St Jules R, Townes-Anderson E (1999) L-type calcium channels in the photoreceptor ribbon synapse: localization and role in plasticity. J Comp Neurol 415:1-16.
Nathan C (1992) Nitric oxide as a secretory product of mammalian cells. FASEB J 6:3051-3064.

Nishiyama M, Hoshino A, Tsai L, Henley JR, Goshima Y, Tessier-Lavigne M, Poo MM, Hong K (2003) Cyclic AMP/GMP-dependent modulation of $\mathrm{Ca}^{2+}$ channels sets the polarity of nerve growth-cone turning. Nature 423:990-995.

Pfeifer A, Ruth P, Dostmann W, Sausbier M, Klatt P, Hofmann F (1999) Structure and function of cGMP-dependent protein kinases. Rev Physiol Biochem Pharmacol 135:105-149.

Polleux F, Morrow T, Ghosh A (2000) Semaphorin 3A is a chemoattractant for cortical apical dendrites. Nature 404:567-573.

Pugh Jr EN, Duda T, Sitaramayya A, Sharma RK (1997) Photoreceptor guanylate cyclases: a review. Biosci Rep 17:429-473.

Raviola E, Gilula NB (1973) Gap junctions between photoreceptor cells in the vertebrate retina. Proc Natl Acad Sci USA 70:1677-1681.

Rieke F, Schwartz EA (1994) A cGMP-gated current can control exocytosis at cone synapses. Neuron 13:863-873.

Savchenko A, Barnes S, Kramer RH (1997) Cyclic-nucleotide-gated channels mediate synaptic feedback by nitric oxide. Nature 390:694-698.

Schmidt H, Werner M, Heppenstall PA, Henning M, More MI, Kuhbandner S, Lewin GR, Hofmann F, Feil R, Rathjen FG (2002) cGMP-mediated signaling via cGKIalpha is required for the guidance and connectivity of sensory axons. J Cell Biol 159:489-498.

Sennlaub F, Courtois Y, Goureau O (2002) Inducible nitric oxide synthase mediates retinal apoptosis in ischemic proliferative retinopathy. J Neurosci 22:3987-3993.

Sherry DM, St Jules RS, Townes-Anderson E (1996) Morphologic and neurochemical target selectivity of regenerating adult photoreceptors in vitro. J Comp Neurol 376:476-488.

Sherry DM, Bui DD, Degrip WJ (1998) Identification and distribution of photoreceptor subtypes in the neotenic tiger salamander retina. Vis Neurosci 15:1175-1187.

Shimizu-Albergine M, Rybalkin SD, Rybalkina IG, Feil R, Wolfsgruber W, Hofmann F, Beavo JA (2003) Individual cerebellar Purkinje cells express different cGMP phosphodiesterases (PDEs): in vivo phosphorylation of cGMP-specific PDE (PDE5) as an indicator of cGMP-dependent protein kinase (PKG) activation. J Neurosci 23:6452-6459.

Song H, Ming G, He Z, Lehmann M, McKerracher L, Tessier-Lavigne M, Poo M (1998) Conversion of neuronal growth cone responses from repulsion to attraction by cyclic nucleotides. Science 281:1515-1518.

Townes-Anderson E, Chawla R, Zhang N (2003) Differential role of cAMP and cGMP in presynaptic plasticity of salamander cone and rod photoreceptors in vitro. Paper presented at Annual Meeting of Association for Research in Vision and Ophthalmology.

Trimm KR, Rehder V (2004) Nitric oxide acts as a slow-down and search signal in developing neurites. Eur J Neurosci 19:809-818.

Ueno S, Bambauer HJ, Umar H, Ueck M (1984) Localization and function of cyclic guanosine monophosphate-phosphodiesterase activity in the retinal rods of the rat by means of a newly developed cytochemical method. Cell Tissue Res 238:453-457.

Van Wagenen S, Rehder V (1999) Regulation of neuronal growth cone filopodia by nitric oxide. J Neurobiol 39:168-185.

Van Wagenen S, Rehder V (2001) Regulation of neuronal growth cone filopodia by nitric oxide depends on soluble guanylyl cyclase. J Neurobiol 46:206-219.

Wang X, Wang W, Li Y, Bai Y, Fiscus RR (1999) Mechanism of SNAP potentiating antiproliferative effect of calcitonin gene-related peptide in cultured vascular smooth muscle cells. J Mol Cell Cardiol 31:1599-1606.

Xiang Y, Li Y, Zhang Z, Cui K, Wang S, Yuan XB, Wu CP, Poo MM, Duan S (2002) Nerve growth cone guidance mediated by $G$ protein-coupled receptors. Nat Neurosci 5:843-848.

Yun HY, Dawson VL, Dawson TM (1996) Neurobiology of nitric oxide. Crit Rev Neurobiol 10:291-316.

Zhang N, Townes-Anderson E (2002) Regulation of structural plasticity by different channel types in rod and cone photoreceptors. J Neurosci 22:7065-7079.

Zhuo M, Hu Y, Schultz C, Kandel ER, Hawkins RD (1994) Role of guanylyl cyclase and cGMP-dependent protein kinase in long-term potentiation. Nature 368:635-639. 